\title{
Design, development and demonstration of a Shallow solar tunnel dryer for non-electrified areas
}

\author{
T. V. Chavda ${ }^{1 *}$, Prem Singh ${ }^{2}$, Sagar Agravat $^{3}$ and S. K. Philip ${ }^{4}$ \\ 1,2 ,3,4 Solar Energy Division, Sardar Patel Renewable Energy Research Institute (SPRERI), Vallabh Vidyanagar-388 \\ 120 (Gujarat), INDIA \\ Present Address: \\ ${ }^{1}$ Department of Renewable Energy Engineering, College of Agricultural Engineering \& Technology, NAU, Dediapada, \\ Narmada -393040 (Gujarat), INDIA \\ ${ }^{2}$ Department of Mechanical Engineering, Guru Nanak Dev Engineering College, Ludhiana (Punjab), INDIA \\ ${ }^{3}$ Renewable Energy R\&D, Gujarat Energy Research \& Management Institute, $1^{\text {st }}$ Floor, Pandit Deendayal Petroleum \\ University Campus, Raisan, Gandhinagar (Gujarat), INDIA \\ *Corresponding author. E-mail : tilak_chavda@yahoo.co.in
}

Received: July 19, 2016; Revised received: July 7, 2017; Accepted: November 6, 2017

\begin{abstract}
This paper presents the design, construction and performance evaluation of a shallow solar tunnel dryer for agro and industrial products. In the shallow solar tunnel dryer, there are three separate units viz.: an air heating unit, drying unit and air diversion unit. Total area of the solar tunnel dryer was $21 \mathrm{~m}^{2}$. The heated air from a separate solar air heating zone is passed through a product bed, and at the same time, the drying tunnel bed absorbs solar energy directly through the transparent UV stabilized plastic sheet used as covering material. This dryer was not required any external sources of the power to operate the electrical fan. The system was designed to operate at a temperature of 50 to $60^{\circ} \mathrm{C}$. The system was installed at the institute and initial testing was conducted. After that the system was also demonstrated at the actual potential user's site. The results obtained during the test period revealed that the temperatures inside the tunnel drying zone and solar air heating zone were much higher than the ambient air temperature during most hours of the day-light. The temperature rise inside the drying tunnel was up to $67.4^{\circ} \mathrm{C}$ at peak hour's period (noon). The drying rate and thermal efficiency of the collector were $1.73 \mathrm{~kg} / \mathrm{h}$ and $26.0 \%$ respectively. The high outlet temperature indicated the scope of loading the dryer further.
\end{abstract}

Keywords: Demonstration, Grid independent dryer, Solar dryer, Solar PV, Tunnel dryer

\section{INTRODUCTION}

Solar air heater is simple device to heat air by utilizing solar energy and employed in many applications requiring low temperature below $65^{\circ} \mathrm{C}$, such as crop drying and space heating (Kurtbas and Turgut, 2006). Drying processes play an important role in the preservation and long term storage of agricultural and industrial products.Many agro and industrial products need to be dried in order to reduce their moisture content for a variety of purposes. While open sun drying or traditional drying may be the most inexpensive, simplest and extensively used option for many of the products in developing countries. Some disadvantages of open air drying are: exposure of the agro-industrial products to rain and dust; uncontrolled drying; exposure to direct sunlight which is undesirable for some agro-industrial products; infestation by insects; attack by animals; etc (Madhlopa et al., 2002). In order to improve traditional drying, solar dryers which have the potential of substantially reducing the above-mentioned disadvantages of open air drying, have received considerable attention over the past 35 years (Bassey, 1989). Solar dryer are found to be technically and economically feasible for many industrial and agricultural products. Several models of solar dryers, having natural or forced convection air circulation modes, have been developed at a number of places to cater to the growing need for quality products (Philip et al., 2003). Solar dryers with natural convection may be relatively slower in operation compared to forced convection systems and hence are mainly used for small scale operations only. Forced circulation based solar dryers provide good control over operating parameters and result in high quality final product, but these are more expensive to own and operate (Philip et al., 2003). As for many products, a less sophisticated dryer would suffice; a few low cost tunnel dryers have been developed. A walk in type solar tunnel dryer developed by Rathore et al. (2002 and 2003) has been in use to dry Dibasic Calcium Phosphate (DCP) in an industry in Rajasthan since many years. Solar tunnel dryers have also been developed in other Countries to meet very specific applications (Eddy et al.,1991 and Joy et 
al., 2001). Solar dryers of the forced convection type can be effectively used. They however need electricity, which unfortunately is non-existent in many rural areas, to operate the fans. Even when electricity exists, the potential users of the dryers are unable to pay for it due to their very low income. Forced convection dryers are for this reason not going to be readily applicable on a wide scale in many developing countries. But, this problem was solved by using the solar photovoltaic panel for producing the electricity on the site. When the solar intensity is high, it will produce more electricity and fan could rotate very fast. Forced circulation solar dryer with PV modules are therefore, the most applicable to the rural areas in developing countries, where the electricity is the major constraints.

Solar drying may be classified into direct, indirect and mixed-modes. In direct solar dryers the air heater contains the agro-industrial products and solar energy passes through a transparent cover and is absorbed by the agro-industrial products. Essentially, the heat required for drying is provided by radiation to the upper layers and subsequent conduction into the agroindustrial bed.

In indirect dryers, solar energy is collected in a separate solar air heater and the heated air then passes through the agro-industrial product bed, while in the mixed-mode type of solar dryer, the heated air from a separate solar air heating zone is passed through a agro-industrial bed, and at the same time, the drying tunnel absorbs solar energy directly through the transparent covering material. Therefore, the objective of this study is to develop a shallow solar tunnel dryer in which the agro-industrial products are dried simultaneously by both direct radiation through the transparent glazing of the tunnel and by the heated air from the solar air heating unit. The performance of the solar tunnel dryer was also evaluated. After studying various models already developed, a shallow solar tunnel dryer for drying agricultural products was designed at SPRERI with the following features to meet the local needs i.e. i) The dryer be low cost, portable and modular in nature, ii) Low cross-sectional area to minimize heat losses in order to obtain high operating temperature, iii) Air flow through the product for better heat transfer and consequently better drying efficiency, iv) Grid independent operation for applications in remote areas not connected to power grid.

\section{MATERIALS AND METHODS}

Dryer design: A modular design approach was adopted for the tunnel dryer so as to be able to scale up the system to meet varied requirements. This system consisted of an air heating unit, drying unit and an air diversion unit. Glass partition was used to separate the air heating and drying units of the dryer to allow passage of solar radiation. All the three units were cov- ered with UV stabilized plastic sheet of 200 micron thickness. Six DC fans with a total airflow potential of 1000 to $1250 \mathrm{~m}^{3} / \mathrm{hr}$ are provided at the outlet of the drying zone. For loading and unloading of products, provision was made for opening the plastic cover. Detailed specifications of the solar tunnel dryer are given in Table 1.

\section{FABRICATION AND SYSTEM DETAILS}

Supporting structure: Supporting structure (Fig. 1) consisted of legs, frames and side plates. MS angle structures of $30^{\prime} 30^{\prime} 5 \mathrm{~mm}$ size were used to fabricate the basic supporting frame. Ten such frames, each of 2 $\mathrm{m}^{\prime} 1 \mathrm{~m}$ size and one frame of $2 \mathrm{~m}^{\prime} 0.5 \mathrm{~m}$ were fixed together to form the complete supporting structure. This supporting structure was mounted on twenty-four legs that had height adjusting facility for leveling the dryer. Twenty-four side plates made of $3 \mathrm{~mm}$ thick MS sheets were fixed to the supporting structure to cover the sides.

Absorber: Ten rectangular boxes of size $2 \mathrm{~m}^{\prime} 1 \mathrm{~m}^{\prime}$ $0.05 \mathrm{~m}$ and one of $2 \mathrm{~m} \mathrm{~m}^{\prime} 0.5 \mathrm{~m} \mathrm{~m}^{\prime} 0.05 \mathrm{~m}$ size were fabricated using Galvanized Iron(GI) sheet of $1.4 \mathrm{~mm}$ thickness and black, selectively coated copper sheets were fixed on top as absorber to trap solar energy. To reduce heat losses from the back of the system, $50 \mathrm{~mm}$ thick Polyurethane Foam insulation was provided. These absorber units were fixed horizontally on the supporting structure.

Air heating, drying and diversion units: The $21 \mathrm{~m}^{2}$ absorber was divided into three parts namely $7.5 \mathrm{~m}^{2}$ of air heating unit, $12.5 \mathrm{~m}^{2}$ drying unit and $1 \mathrm{~m}^{2}$ diversion unit. The $4 \mathrm{~mm}$ thick glass used to separate the air heating and drying units acted as a transparent media to trap solar radiation to heat the drying unit. Stainless steel wire mesh was used for holding products for drying in the drying unit. Three baffles of $20 \mathrm{~cm}$ height were provided in the diversion unit for smooth change in the direction of airflow from heating unit to drying

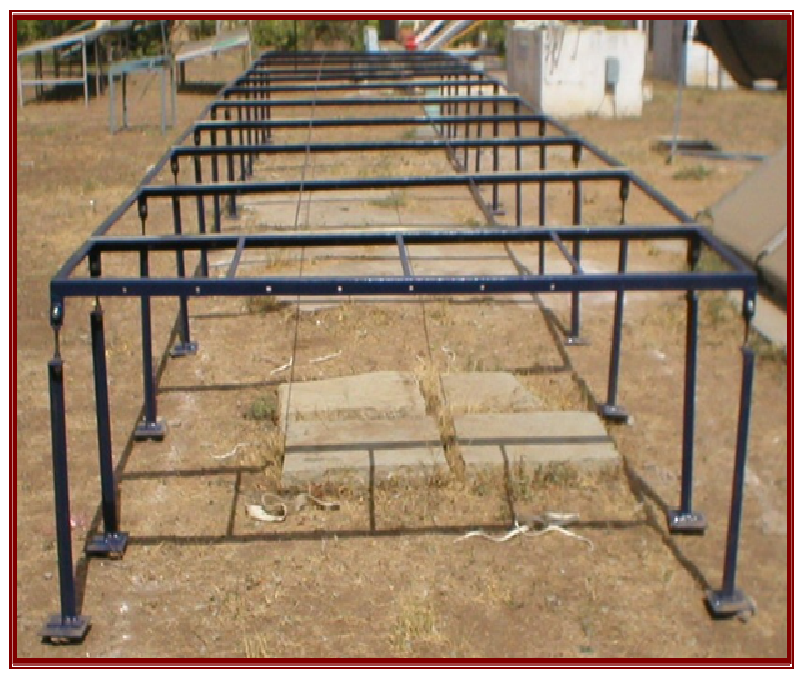

Fig. 1. Dryer supporting structure. 
unit (Fig. 2). These baffles were also blackened to absorb maximum solar radiation.

Glazing: Air heating, drying and diversion units were covered with UV (Ultra Violet) stabilized plastic sheet of 200 micron thickness fixed to glazing support structure made of $12.5 \mathrm{~mm}$ diameter GI pipes. Both ends of the pipe were fixed to the side plates with nut and bolt arrangement. Glazing was fixed on side plates with the help of $U$ shaped rubber gripper to facilitate easy opening and closing for loading and unloading.

Air flow arrangement: At the air inlet, a wire mesh of $0.168 \mathrm{~m}^{\prime} 0.15 \mathrm{~m}$ size was provided to restrict entry of dust, birds, insects etc. in to the dryer. At the outlet end of the drying unit, six DC fans of $10 \mathrm{~cm}$ diameter were installed in such a way as to flow hot air from air heating unit into the drying unit and pump out the moist air. Two $30 \mathrm{~W}_{\mathrm{p}}$ Solar Photovoltaic (SPV) modules were installed facing south to power the six DC fans (Fig. 3). The DC fans would operate whenever the solar cells were able to provide adequate output to operate the fans. This arrangement ensured fan operation only when the sun was shining and the tunnel dryer was warm.

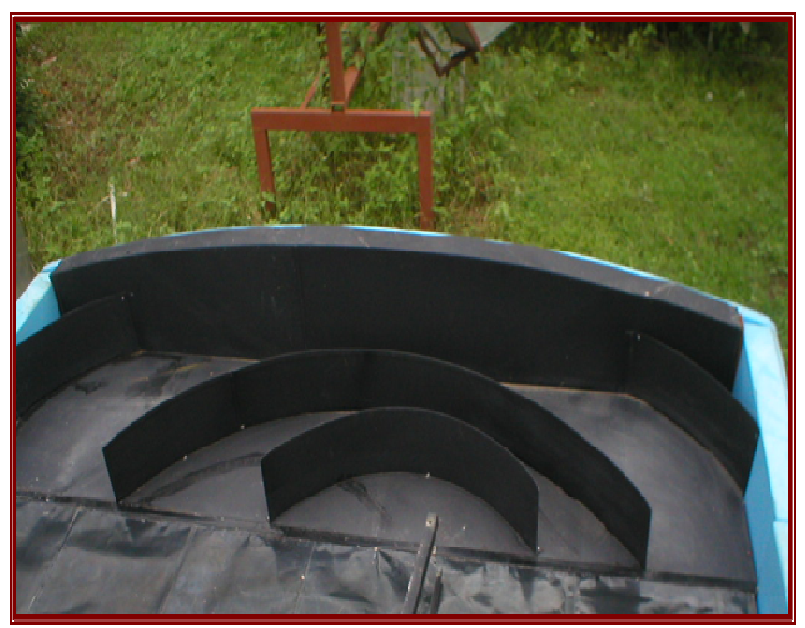

Fig. 2. Three baffles fixed in diversion unit.

\section{RESULTS AND DISCUSSION}

Performance evaluation: The shallow solar tunnel dryer shown in Fig. 4 was tested in the months of November and January of the winter season to evaluate its performance. Testing of the shallow solar tunnel dryer involved no load temperature test and test with part load conducted in about four months time. Temperature at the inlet end of heating unit and outlet were monitored along with ambient temperature at regular interval of half an hour between the hours of 10:00 and 16:00 local time. Solar insolation on horizontal plane was measured by means of a portable pyranometer. Test results obtained for one day during the different months is shown in Table $2 \mathrm{a}$ and $2 \mathrm{~b}$. As the dryer was not loaded, the whole dryer functioned as air heater and about 15 to $18^{\circ} \mathrm{C}$ gain in air temperature was obtained by the time air reached the end of the heating unit. This gain was found to be adequate for drying many agro products, the same was also presented by Philip et al.(2003) and Philip (2003).

More elaborate tests were conducted subsequently and the system was found to function as per expectations. More temperature sensors were installed inside the tunnel dryer to obtain the temperature gain as the air moved through the dryer. Sensors were placed at the inlet, outlet and at four positions in between. At each point, two T type thermocouple sensors were placed to improve the data accuracy. Besides this, airflow due to the DC fans operated on solar cells was monitored with the help of hand held anemometer. Temperature data and thermal efficiency obtained during no load tests conducted on a day in March are shown in Table 3. Intermediate air temperature obtained at different positions inside the solar dryer for a whole day is shown in Fig. 4. As can be seen from the tables and the graph, the air temperature inside the dryer increased till about $1 \mathrm{pm}$ ad there after started to decrease. In the dryer, without load, the temperature gain continued throughout the length of the dryer with the maximum

Table 1. Technical specifications of shallow solar tunnel dryer.

\begin{tabular}{lll}
\hline S. No. & Parameters & Dimensions and characteristics \\
\hline 1 & Total surface area & $21 \mathrm{~m}^{2}$ \\
& Air heating area & $7.5 \mathrm{~m}^{2}$ \\
& Drying unit area & $12.5 \mathrm{~m}^{2}$ \\
& Diversion unit area & $1 \mathrm{~m}^{2}$ \\
2 & Loading capacity & 60 to $100 \mathrm{kgs}$ per batch \\
3 & Absorber material & Selectively coated copper sheet of $0.4 \mathrm{~mm}$ thickness \\
4 & Cover material & 200 micron UV stabilized plastic sheet \\
5 & Air flow rate & 1000 to $1250 \mathrm{~m}$ /hr \\
6 & Air flow arrangement & Six DC fans operating on SPV modules \\
7 & Insulation & $50 \mathrm{~mm}$ thick Polyurethane Foam \\
8 & Partition between Air heating and drying unit & 4 mm thick glass sheets \\
9 & Product holder & Stainless steel wire mesh \\
\hline
\end{tabular}


T. V. Chavda et al. / J. Appl. \& Nat. Sci. 9 (4): 2461 - 2468 (2017)

dryer temperature touching close to $70^{\circ} \mathrm{C}$. It can be seen from Fig. 4 that at the inlet to the drying chamber the maximum temperature was about $60^{\circ} \mathrm{C}$ which is appropriate for most agro products.

It was observed that during the day, the inside heating unit temperature exceeded due to black painted absorber rapidly, which increases the inside air temperature throughout the heating unit and it reached maximum above $60^{\circ} \mathrm{C}$ at solar noon. The role of inside heated air was to refresh the product through creating a draft. Similar temperature behavior for drying different crops in the tunnel drying was also presented by Rathore et al. (2002 and 2003).

Table 2a. Performance data of the solar tunnel dryer without load (November).

\begin{tabular}{ccccccc}
\hline $\begin{array}{c}\text { Time } \\
\text { (hrs) }\end{array}$ & $\begin{array}{c}\text { Ambient } \\
\text { Temperature } \\
{ }^{\circ} \mathbf{C}\end{array}$ & $\begin{array}{c}\text { Solar } \\
\text { radiation W/ } \\
\mathbf{m}^{\mathbf{2}}\end{array}$ & Inlet & $\begin{array}{c}\text { Temperature }{ }^{\circ} \mathbf{C} \\
\text { End of heating } \\
\text { unit }\end{array}$ & Outlet & $\begin{array}{c}\text { Temperature gain } \\
{ }^{\circ} \mathbf{C}\end{array}$ \\
\hline 10:00 & 29.5 & 446.3 & 30.3 & 45.1 & 50.2 & 19.9 \\
10:30 & 30.3 & 521.4 & 31.7 & 46.7 & 53.4 & 21.7 \\
$11: 00$ & 31.9 & 583.5 & 32.9 & 51.3 & 55.8 & 22.9 \\
$11: 30$ & 33.4 & 626.7 & 33.3 & 51.5 & 57.5 & 24.3 \\
$12: 00$ & 34.1 & 650.6 & 34.7 & 52.3 & 61.6 & 26.9 \\
$12: 30$ & 34.9 & 666.6 & 34.5 & 53.3 & 64.9 & 30.4 \\
$13: 00$ & 36.1 & 691.8 & 35.3 & 54.9 & 66.1 & 30.8 \\
$13: 30$ & 36.5 & 633.7 & 36.2 & 54.1 & 65.8 & 29.7 \\
$14: 00$ & 37.1 & 590.9 & 37.0 & 55.6 & 64.1 & 27.1 \\
$14: 30$ & 37.5 & 527.0 & 37.4 & 54.9 & 62.0 & 24.6 \\
$15: 00$ & 37.6 & 454.6 & 36.6 & 53.2 & 58.4 & 21.8 \\
$15: 30$ & 38.0 & 377.6 & 35.2 & 50.0 & 55.2 & 20.0 \\
$16: 00$ & 37.4 & 279.7 & 35.5 & 47.4 & 52.5 & 17.1 \\
\hline
\end{tabular}

Table 2b. Performance data of solar tunnel dryer without load (January).

\begin{tabular}{|c|c|c|c|c|c|c|}
\hline \multirow{2}{*}{$\begin{array}{l}\text { Time } \\
\text { (hrs) }\end{array}$} & \multirow{2}{*}{$\begin{array}{c}\text { Ambient } \\
\text { Temperature } \\
{ }^{\circ} \mathrm{C}\end{array}$} & \multirow{2}{*}{$\begin{array}{c}\text { Solar } \\
\text { radiation } \mathrm{W} / \\
\mathrm{m}^{2}\end{array}$} & \multicolumn{3}{|c|}{ Temperature ${ }^{\circ} \mathrm{C}$} & \multirow{2}{*}{$\begin{array}{c}\text { Temperature gain } \\
{ }^{\circ} \mathrm{C}\end{array}$} \\
\hline & & & Inlet & $\begin{array}{c}\text { End of heating } \\
\text { unit }\end{array}$ & Outlet & \\
\hline $10: 00$ & 18.3 & 406.3 & 20.2 & 32.9 & 37.1 & 16.9 \\
\hline $10: 30$ & 20.2 & 501.2 & 21.6 & 34.1 & 39.3 & 17.7 \\
\hline 11:00 & 21.9 & 553.8 & 22.5 & 36.3 & 41.3 & 18.8 \\
\hline $11: 30$ & 22.8 & 606.4 & 23.2 & 37.6 & 42.4 & 19.2 \\
\hline $12: 00$ & 24.2 & 640.2 & 25.3 & 38.1 & 46.1 & 20.8 \\
\hline $12: 30$ & 25.3 & 665.9 & 25.9 & 40.3 & 48.5 & 22.6 \\
\hline $13: 00$ & 26.7 & 689.2 & 26.9 & 42.9 & 50.2 & 23.3 \\
\hline $13: 30$ & 27.9 & 644.2 & 28.2 & 45.1 & 53.3 & 25.1 \\
\hline $14: 00$ & 28.5 & 599.9 & 29.0 & 46.6 & 54.4 & 25.4 \\
\hline $14: 30$ & 28.9 & 501.6 & 29.3 & 45.9 & 52.5 & 23.2 \\
\hline $15: 00$ & 29.1 & 465.3 & 29.6 & 45.1 & 50.3 & 20.7 \\
\hline $15: 30$ & 28.6 & 389.8 & 28.9 & 42.2 & 46.9 & 18.0 \\
\hline $16: 00$ & 27.5 & 306.1 & 28.0 & 41.8 & 43.0 & 15.0 \\
\hline
\end{tabular}

Table 3. Temperature, air flow and efficiency during no load test in March month.

\begin{tabular}{|c|c|c|c|c|c|c|c|c|c|}
\hline \multirow[t]{2}{*}{ Time } & \multirow{2}{*}{$\begin{array}{c}\text { Solar } \\
\text { insolation } \\
\mathrm{W} / \mathbf{m}^{2}\end{array}$} & \multirow[t]{2}{*}{$\begin{array}{l}\text { Ambient tem- } \\
\text { perature }{ }^{\circ} \mathrm{C}\end{array}$} & \multicolumn{2}{|c|}{$\begin{array}{c}\text { Dryer } \\
\text { temperature, }{ }^{\circ} \mathrm{C} \\
\end{array}$} & \multicolumn{3}{|c|}{$\begin{array}{c}\text { Relative humidity } \\
\%\end{array}$} & \multirow{2}{*}{$\begin{array}{c}\text { Air flow } \\
\text { rate } \\
\mathrm{m}^{3} / \mathrm{hr}\end{array}$} & \multirow[t]{2}{*}{$\begin{array}{c}\text { Efficiency } \\
\%\end{array}$} \\
\hline & & & Inlet & Outlet & Inlet & Intermediate & Outlet & & \\
\hline $10: 00$ & 570.67 & 28.00 & 30.90 & 55.00 & 61.00 & 51.00 & 48.00 & 295.92 & 16.53 \\
\hline $10: 30$ & 671.07 & 29.50 & 31.90 & 56.50 & 48.00 & 43.00 & 39.00 & 517.86 & 25.11 \\
\hline 11:00 & 758.25 & 32.00 & 31.20 & 58.20 & 57.00 & 41.00 & 42.00 & 536.35 & 25.26 \\
\hline $11: 30$ & 811.09 & 32.50 & 33.30 & 63.75 & 55.00 & 41.00 & 38.00 & 536.35 & 26.63 \\
\hline $12: 00$ & 862.61 & 34.00 & 34.50 & 62.95 & 53.00 & 37.00 & 38.00 & 591.84 & 25.81 \\
\hline $12: 30$ & 871.86 & 35.00 & 36.90 & 66.15 & 50.00 & 37.00 & 34.00 & 536.35 & 23.80 \\
\hline $13: 00$ & 875.82 & 36.00 & 36.10 & 66.80 & 45.00 & 37.00 & 29.00 & 554.84 & 25.72 \\
\hline $13: 30$ & 866.57 & 38.00 & 36.20 & 67.40 & 41.00 & 36.00 & 35.00 & 480.87 & 22.90 \\
\hline $14: 00$ & 834.87 & 37.00 & 35.60 & 63.30 & 41.00 & 36.00 & 33.00 & 499.36 & 21.91 \\
\hline $14: 30$ & 797.86 & 38.00 & 35.30 & 62.35 & 39.00 & 35.00 & 33.00 & 480.87 & 21.56 \\
\hline $15: 00$ & 715.96 & 37.50 & 34.80 & 60.45 & 37.00 & 35.00 & 32.00 & 480.87 & 22.78 \\
\hline $15: 30$ & 532.36 & 38.00 & 33.30 & 52.00 & 37.00 & 35.00 & 33.00 & 406.89 & 18.90 \\
\hline $16: 00$ & 546.85 & 37.50 & 34.80 & 50.50 & 36.00 & 35.00 & 34.00 & 406.89 & 18.40 \\
\hline $16: 30$ & 437.25 & 37.50 & 33.80 & 44.95 & 40.00 & 36.00 & 38.00 & 443.88 & 14.97 \\
\hline $17: 00$ & 297.22 & 37.00 & 32.80 & 41.30 & 41.00 & 36.00 & 41.00 & 447.96 & 5.60 \\
\hline
\end{tabular}


T. V. Chavda et al. / J. Appl. \& Nat. Sci. 9 (4): 2461 - 2468 (2017)

Table 4. Performance data during drying trial on solar tunnel dryer Product : $26 \mathrm{~kg}$ Green Chilly.

\begin{tabular}{|c|c|c|c|c|c|c|c|c|}
\hline \multirow[t]{2}{*}{ Time } & \multirow{2}{*}{$\begin{array}{c}\text { Solar insolation } \\
\mathrm{W} / \mathrm{m}^{2}\end{array}$} & \multirow{2}{*}{$\begin{array}{c}\text { Ambient } \\
\text { temperature }^{\circ} \mathrm{C}\end{array}$} & \multicolumn{2}{|c|}{ Dryer temperature $^{\circ} \mathrm{C}$} & \multicolumn{2}{|c|}{ Relative humidity, \% } & \multirow{2}{*}{$\begin{array}{c}\text { Air flow } \\
\text { rate } \\
\mathbf{m}^{3} / \mathrm{hr}\end{array}$} & \multirow{2}{*}{$\begin{array}{l}\text { Product mois- } \\
\text { ture content, } \\
\%(w b)\end{array}$} \\
\hline & & & Inlet & Outlet & Inlet & Outlet & & \\
\hline \multicolumn{9}{|c|}{ First day (March month) } \\
\hline $11: 00$ & 830.90 & 31.50 & 36.50 & 63.70 & 31.00 & 27.00 & 332.74 & 86.25 \\
\hline $13: 00$ & 927.34 & 34.00 & 39.40 & 71.60 & 40.00 & 31.00 & 443.88 & \\
\hline $15: 00$ & 724.40 & 37.00 & 37.60 & 56.70 & 39.00 & 37.00 & 436.36 & \\
\hline $17: 00$ & 311.75 & 36.00 & 34.40 & 42.60 & 39.00 & 40.00 & 203.45 & 44.25 \\
\hline \multicolumn{9}{|c|}{ Second day (March month) } \\
\hline $10: 00$ & 570.67 & 28.00 & 30.90 & 55.00 & 61.00 & 48.00 & 295.92 & 32.91 \\
\hline $12: 00$ & 862.61 & 34.00 & 34.50 & 62.95 & 53.00 & 38.00 & 591.84 & \\
\hline $14: 00$ & 834.87 & 37.00 & 35.60 & 63.30 & 41.00 & 33.00 & 499.36 & \\
\hline $16: 00$ & 546.85 & 37.50 & 34.80 & 50.50 & 36.00 & 34.00 & 406.89 & \\
\hline $17: 00$ & 297.22 & 37.00 & 32.80 & 41.30 & 41.00 & 41.00 & 447.96 & 10.00 \\
\hline
\end{tabular}

Table 5. Products evaluated in the SPRERI solar tunnel dryer.

\begin{tabular}{cllc}
\hline $\begin{array}{c}\text { Sr. } \\
\text { No. }\end{array}$ & Product & Form & No. of experiments \\
\hline 1. & Tomato & Vertically cut into eight pieces & 2 \\
2. & Chili & Without cutting & 1 \\
3. & Fish (Bombay Duck) & $\begin{array}{l}\text { Soaked in saline water for half hour, hung with pins as single } \\
\text { piece. }\end{array}$ & 2 \\
4. & Onion & Cut into thin slices & 1 \\
5. & Amla & Boiled for half an hour and cut into 6 to 7 pieces & 2 \\
6. & Sweet Amla & Sugar treated for seven days \& cut into 6-7 pieces & 3 \\
\hline
\end{tabular}

Table 6. Summary of the experimental results.

\begin{tabular}{clcccc}
\hline $\begin{array}{c}\text { Sr. } \\
\text { No. }\end{array}$ & Product & $\begin{array}{c}\text { Weight (kg) } \\
\text { during each } \\
\text { experiment }\end{array}$ & $\begin{array}{c}\text { Percentage moisture content (W.B.) } \\
\text { Initial }\end{array}$ & $\begin{array}{c}\text { Frying duration } \\
\text { (hrs.) }\end{array}$ \\
\hline 1. & Tomato & 39.90 & 88.50 & 10.0 & 18.50 \\
2. & Chili & 40.00 & 85.50 & 12.00 & 12.50 \\
3. & Fish (Bombay Duck) & 32.00 & 90.00 & 16.50 & 15.50 \\
4. & Onion & 55.26 & 60.00 & 12.30 & 28.00 \\
5. & Amla & 68.00 & 65.00 & 9.00 & 12.50 \\
6. & Sweet Amla Candy & 60.00 & 45.00 & 28.00 & 7.00 \\
\hline
\end{tabular}

Drying trail was conducted on the solar tunnel dryer by loading fresh green chillies in the shallow solar tunnel dryer in the month of March. Whole chillies loaded were found to dry in two sunny days but resulted in slight colour variation. The drying data obtained are given in Table 4 . The tunnel dryer was able to remove moisture, wet basis, (from initial moisture content of about $87 \%$ to $10 \%$ final moisture content) from $26 \mathrm{~kg}$ of green chillies in two days of $15.00 \mathrm{~h}$ drying time, which is about $1.73 \mathrm{~kg} / \mathrm{h}$ drying rate. In the other words, the samples were dried in the two days indicating drying rate of about half a $\mathrm{kg}$ of water per sq. $\mathrm{m}$. area per day. The high outlet temperature indicates the scope of loading the dryer further.

The dryer was loaded with whole green chillies (single layer average thickness) and its weight was measured

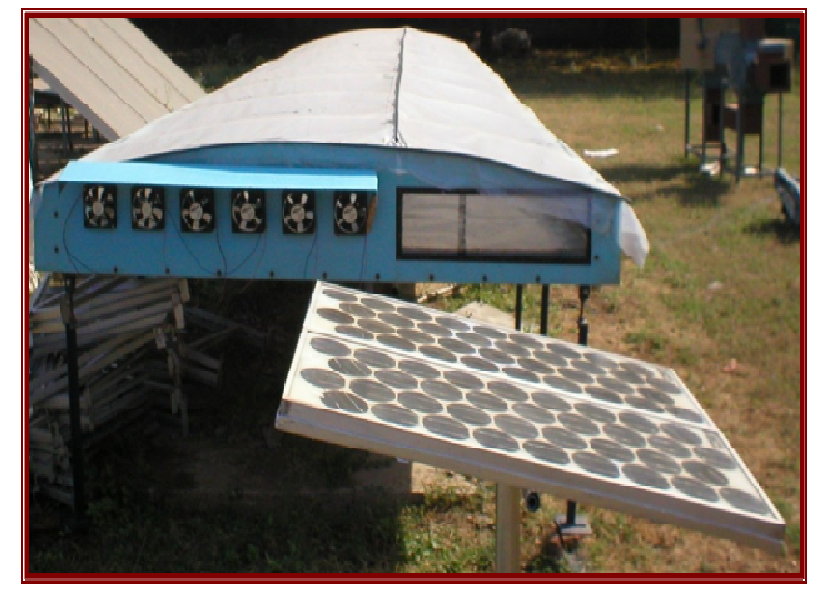

Fig. 3. Six DC fans and solar photovoltaic modules. 
T. V. Chavda et al. / J. Appl. \& Nat. Sci. 9 (4): 2461 - 2468 (2017)

Table 7. Data collected on sweet Amla drying experiments.

\begin{tabular}{|c|c|c|c|c|c|c|}
\hline \multirow[t]{2}{*}{ Time (IST) } & \multicolumn{3}{|c|}{ Temperature ${ }^{\circ} \mathbf{C}$} & \multirow{2}{*}{$\begin{array}{c}\text { Temperature gain, }^{\circ} \\
\text { C }\end{array}$} & \multicolumn{2}{|c|}{ Relative humidity, \% } \\
\hline & Inlet & Air heater outlet & Dryer outlet & & Inlet & Outlet \\
\hline \multicolumn{7}{|c|}{ Experiment 1} \\
\hline $9: 45$ & 23.8 & 32.3 & 26.5 & 2.7 & 45 & 71 \\
\hline $10: 15$ & 24.1 & 33.6 & 32.2 & 8.1 & 44 & 72 \\
\hline $10: 45$ & 24.1 & 35.7 & 33.2 & 9.1 & 53 & 64 \\
\hline $11: 15$ & 26.7 & 37.4 & 34.2 & 7.5 & 50 & 62 \\
\hline $11: 45$ & 28.7 & 38.5 & 37.2 & 8.5 & 50 & 60 \\
\hline $12: 15$ & 29.8 & 39.8 & 38.5 & 8.7 & 48 & 58 \\
\hline $12: 45$ & 31.1 & 41.2 & 39.8 & 9.4 & 45 & 57 \\
\hline $13: 15$ & 31.3 & 41.6 & 40.7 & 8.0 & 45 & 55 \\
\hline $13: 45$ & 32.9 & 42.6 & 40.9 & 7.6 & 44 & 54 \\
\hline $14: 15$ & 31.7 & 40.5 & 39.3 & 7.2 & 44 & 52 \\
\hline $14: 45$ & 31.8 & 40.6 & 39.0 & 5.2 & 44 & 52 \\
\hline $15: 15$ & 29.1 & 39.5 & 34.3 & 4.1 & 44 & 52 \\
\hline $15: 45$ & 29.3 & 38.7 & 33.4 & 4.1 & 44 & 55 \\
\hline 16:00 & 29 & 37 & 30.5 & 1.5 & 44 & 54 \\
\hline \multicolumn{7}{|l|}{ Experiment 2} \\
\hline $9: 45$ & 20.1 & 32.3 & 22 & 1.9 & 45 & 68 \\
\hline $10: 15$ & 23.1 & 36 & 31 & 7.9 & 44 & 65 \\
\hline $10: 45$ & 23.2 & 34.7 & 35.2 & 12 & 50 & 55 \\
\hline $11: 15$ & 24.7 & 35.2 & 37 & 12.3 & 48 & 54 \\
\hline $11: 45$ & 27.1 & 38.3 & 41.1 & 14 & 45 & 51 \\
\hline $12: 15$ & 30.1 & 40.5 & 44.8 & 14.7 & 43 & 50 \\
\hline $12: 45$ & 30.4 & 44.8 & 45.3 & 14.9 & 43 & 49 \\
\hline $13: 15$ & 30.5 & 41.8 & 46.7 & 16.2 & 40 & 47 \\
\hline $13: 45$ & 31.5 & 41.5 & 47.4 & 15.9 & 40 & 47 \\
\hline $14: 15$ & 32.1 & 39.1 & 45.2 & 13.1 & 39 & 47 \\
\hline $14: 45$ & 31.3 & 39.1 & 45.6 & 14.3 & 39 & 47 \\
\hline $15: 15$ & 30.3 & 38.8 & 45.2 & 14.9 & 39 & 47 \\
\hline $15: 45$ & 29.6 & 38.5 & 44.8 & 15.2 & 39 & 47 \\
\hline
\end{tabular}

Table 8. Products dried at M/s. Mashika Agritech, Itola.

\begin{tabular}{clccc}
\hline $\begin{array}{c}\text { Sr. } \\
\text { No. }\end{array}$ & \multicolumn{1}{c}{ Item dried } & Quantity (kg) & $\begin{array}{c}\text { Quantity } \\
\text { Recovered (kg) }\end{array}$ & $\begin{array}{c}\text { Drying duration } \\
\text { (hours) }\end{array}$ \\
\hline 1 & Coriander & 40 & 2.8 & $5-6$ \\
2 & Fenugreek leaves & 38 & 2 & $6-7$ \\
3 & Drumstick leaves & 56 & 5.2 & $5-6$ \\
4 & Neem leaves & 80 & 6 & $5-6$ \\
5 & Capsicum (Simlamirch) & 10 & 800 gm & $12-13$ \\
6 & Ginger & 25 & 2.2 & $24-25$ \\
7 & Potato Wafers & 10 & 1 & $7-8$ \\
\hline
\end{tabular}

at the start and at the end of each drying days thereafter. Knowing the initial weight and the final weight at the point when no further weight loss of green chillies was attained, the weight loss was used to calculate the moisture removed in $\mathrm{kg}$ water $/ \mathrm{kg}$ dry matter at intervals as the chillies dried. The dryer performance was evaluated using the drying rate and collector efficiency [Joy et.al. (2001) and Philip et.al. (2003)]. The thermal efficiency of the collector was computed using equation (1) and the drying rate, which is the quantity of moisture removed from the food item in a given time, was computed from equation (2) below:

$$
\eta_{g}=\frac{Q_{g}}{A_{\varepsilon} I_{T}}
$$

Where, $\mathrm{h}_{\mathrm{c}}=$ thermal efficiency of the collector $\% \mathrm{Q}_{\mathrm{g}}=$ Heat gain by the air

$\mathrm{A}_{\mathrm{c}}=$ Collector area, $\mathrm{m}^{2}$

$\mathrm{I}_{\mathrm{T}}=$ Total solar radiation incident on the top surface

$$
\frac{d M}{d t}=\left(\frac{M_{i}-M_{f}}{t}\right) \times 100 \%
$$

The construction of the tunnel dryer was found to facilitate easy loading and unloading of the product for drying. The height of the system permitted a person of 
average built to operate the dryer without difficulty. The temperature obtained in the dryer indicated it's suitability for drying many agro products.

After conducting preliminary experiments to ensure smooth operation, the setup was used for conducting drying experiments to obtain essential data for evaluating the performance of solar tunnel dryer with different products. Performance of the dryers for load condition in different seasons was also studied. A total of five different products were evaluated from April to December. Table 5 lists the products dried, the form of product and the number of experiments conducted for each product. Table 6 gives the information about the drying parameters.

\section{DEMONSTRATION}

After successful completion of the testing of solar tunnel dryer for a few important products, one user, M/s. Rasbihari Enterprises Ltd., a sweet amla candy producer, showed great interest for installing system for their work. It was decided to conduct some preliminary experiments on the system at SPRERI itself to generate scientific information on amla candy drying; system was to shift at their site after signing proper agreement with the institute. The user was satisfied with the system performance and is planning to install a dryer to meet their requirements. Initial mois- ture content of the processed Amlawas about $45 \%$ (w.b.) and desired final moisture content was about $25 \%$. Complete drying took about seven hours for bringing the moisture content down to the desired level. Table 7 gives the detail drying data collected by $\mathrm{M} / \mathrm{s}$. Rasbihari Enterprise at the institute.

Meanwhile the system has been transferred to $\mathrm{M} / \mathrm{s}$. MashikaAgritech Pvt. Ltd., at village Itola, for further field evaluation. The user is engaged in the business of growing and selling of Oyster Mushroom and preparation of different mushroom based Ayurvedic medicines using SPRERI designed forced convention solar dryer and wished to expand their activity for a few more products. Fig. 5 shows the SPRERI solar tunnel dryer installed on the terrace at user's site and the system in loaded condition with Neem leaves.

\section{USER'S FEEDBACK}

The user tested the system for a few selected products during the month of October-November. Results are tabulated as shown in Table 8.

\section{COST ECONOMICS}

Cost economics of the SPRERI solar tunnel dryer has been worked out and was compared with a similar capacity electrical dryer working at M/s. Rasbihari Enterprises, for drying sweet Amla candy.

\begin{tabular}{|c|c|c|c|}
\hline Sr. No. & Description & Solar Tunnel Dryer & Electrical Dryer \\
\hline 1 & Cost,Rs. & 70,000 & 37,500 \\
\hline 2 & Useful life, years & 10 & 10 \\
\hline 3 & Loading capacity, $\mathrm{kg} /$ day & 60 & 60 \\
\hline 4 & Working day per year & 250 & 300 \\
\hline 5 & Product dried, $\mathrm{kg} / \mathrm{year}$ & 15,000 & 18,000 \\
\hline 6 & Blower capacity, hp & 0 & 0.6 \\
\hline 7 & Electrical heater, $\mathrm{kW}$ & 0 & 6 \\
\hline 8 & Operation time of heater, $\mathrm{hr} / \mathrm{day}$ & 0 & 8 \\
\hline 9 & Electricity consumption, $\mathrm{kWh}$ & 0 & 48 \\
\hline 10 & Annual interest rate, $\%$ & 12 & 12 \\
\hline 11 & Salvage value, $\%$ of the cost & 10 & 10 \\
\hline 12 & Annual repair and maintenance, $\%$ of cost & 3 & 5 \\
\hline \multicolumn{4}{|c|}{ ANNUAL COST, Rs. } \\
\hline 13 & Interest on average cost & 8,400 & 4,500 \\
\hline 14 & Depreciation@ @\% & 6,300 & 3,375 \\
\hline \multirow[t]{3}{*}{15} & Repair and maintenance & 2,100 & 1,875 \\
\hline & Sub Total Rs./year & 16,800 & 9,750 \\
\hline & Rs./day & 67.2 & 32.5 \\
\hline \multicolumn{4}{|c|}{ OPERATING COSTS, RS./DAY } \\
\hline 16 & Electricity@ Rs.4.5/kWh & 0 & 216 \\
\hline \multirow[t]{2}{*}{17} & Labour@ Rs.150 & 75 & 75 \\
\hline & Sub Total Rs./day & 75 & 291 \\
\hline \multicolumn{4}{|c|}{ COST OF DRYING } \\
\hline & Rs./day & 142.2 & 323.5 \\
\hline & Rs./kg & 2.37 & 5.391 \\
\hline
\end{tabular}

Savings/year: Rs. 46,215/-; Payback period : 1.5 Years 


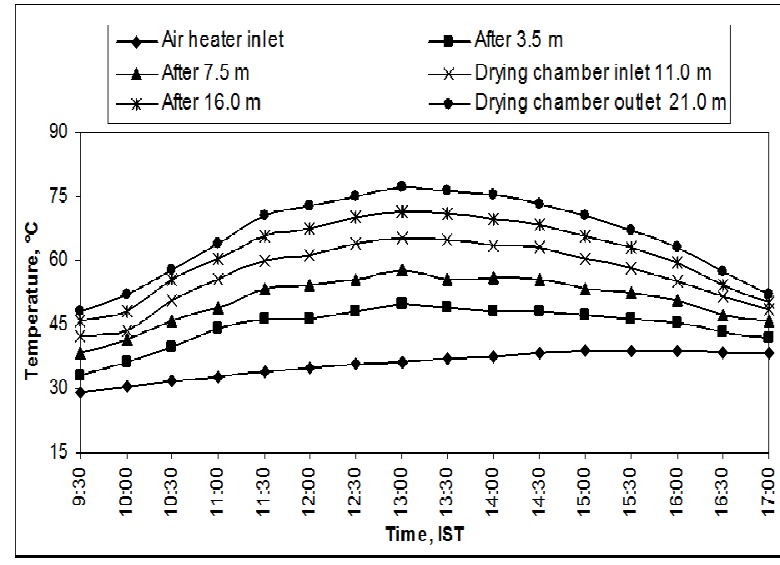

Fig. 4. Temperature profile in the tunnel dryer during no load test .

\section{Conclusion}

A solar tunnel dryer of $21 \mathrm{~m}^{2}$ are divided into two parts, one for air heating and the other for loading product has been successfully developed and demonstrated at user site also. The system has been designed in a modular fashion for easy scaling up. An intermediate zone called diversion unit is built between the heating and drying zones and this can be used to introduce a thermal backup for the dryer if it becomes necessary for a specific application. The temperatures obtained in the dryer indicate the possibility of using the system for many agro products. The cost of the system also can afford by the community farmer as well as payback period is also less than two years. This system can be efficiently used for drying purposes in remote areas, far away from the main electricity or areas without reliable energy supplies or in farmers field itself due to grid independent operation of the system. The tunnel dryer was able to remove moisture, wet basis, (from initial moisture content of about $87 \%$ to $10 \%$ final moisture content) from $26 \mathrm{~kg}$ of green chillies in two days of $15.00 \mathrm{~h}$ drying time, which is about $1.73 \mathrm{~kg} / \mathrm{h}$ drying rate. In the other words, the samples were dried in the two days indicating drying rate of about half a $\mathrm{kg}$ of water per sq. m. area per day. The high outlet temperature indicated the scope of loading the dryer further.

\section{ACKNOWLEDGEMENTS}

Financial support provided by Indian Council of Agricultural Research, New Delhi for this work is grate-

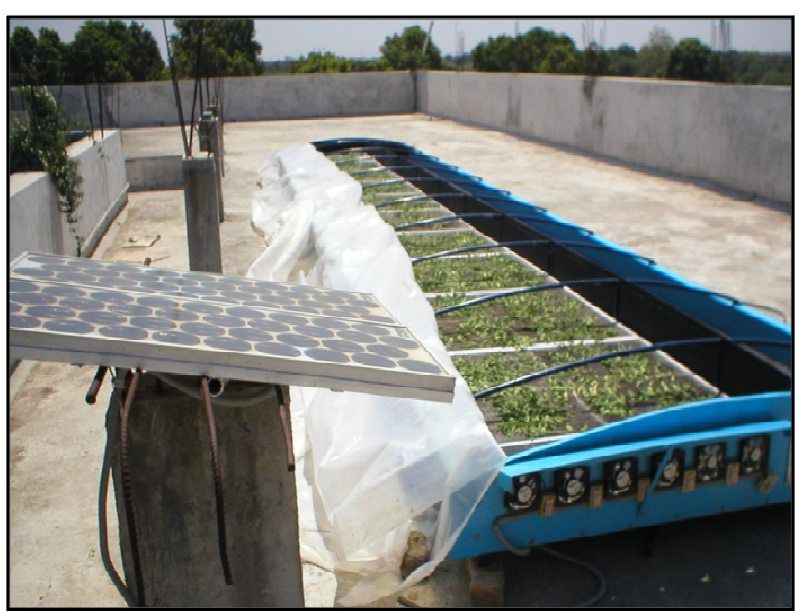

Fig. 5. Solar tunnel dryer installed on the terrace of building at M/s. Mashika Agritech, Itola.

fully acknowledged. Authors are highly thankful to Director as well as all the staffs of Solar Energy Division, Sardar Patel Renewable Energy Research Institute (SPRERI), Vallabh Vidyanagar, Dist. Anand, Gujarat for their kind support and facility.

\section{REFERENCES}

Bassey, M.W. (1989) Development and use of solar drying technologies, Nigerian Journal of Solar Energy. 89:133164.

Eddy J. Amir, K. Grandegger and et. al. (1991) Development of a Multi - Purpose Solar Tunnel Dryer for Use in Humid Tropics. Solar Energy. 1(2):167-176.

Joy, C. M., George, P. P., and Jose, K. P. (2001) Solar Tunnel Drying of Red Chillies (Capsicum annum L.), J. Food Sci Technology. 38(3):213-216.

Kurtbas, I. and Turgut, E. (2006) Experimental investigation of solar air heater with free and fixed fins: efficiency and energy loss. International Journal of Science and Technology. 1(1):75-82.

Madhlopa, A, Jones, S.A. and Kalenga-Saka, J.D. (2002) A solar air heater with composite absorber systems for food dehydration. Renewable Energy. 27:27-37.

Philip, S. K. (2003) Drying through Solar Energy. IREDA NEWS. 14(2):53-55.

Philip, S. K. and Singh, P. (2003) Solar Dryers, A Guide for Potential Users and Implementers, Sardar Patel Renewable Energy Research Institute, Vallabh Vidyanagar.

Rathore, N. S. (2003) Industrial Application of Solar Tunnel Dryer. IREDA NEWS. 14(2):49-51.

Rathore, N. S. and Kothari S., (2002) Technical bulletin on "Agro-industrial Application of Solar Tunnel Dryer" Coordinating Cell AICRP on Renewable Sources of Energy, Central Institute of Agricultural Engineering. 